\title{
A BALATONI NÁDASOK PUSZTULÁSA ÉS REGENERÁCIÓJA A MEDERDINAMIKA FÜGGVÉNYÉBEN
}

\author{
GYENESE TAMÁS - ZLINSZKY ANDRÁS - ALBERT GÁSPÁR \\ DIE-BACK AND REGENERATION OF REED WETLANDS ON LAKE BALATON \\ IN CONNECTION WITH LOCAL SEDIMENT DYNAMICS
}

\begin{abstract}
The coastal wetlands of Lake Balaton are the most diverse habitats of the lake and are essential for the regeneration of fish stocks and for shore protection. The area of these wetlands has been decreasing for the last decades, and previous studies have demonstrated that this is in connection with raised and stabilized water levels. However, to date the effect of changes of lake bottom topography on reed stands has not been investigated. Our objective was to compare the lake bottom surveys of 1975 and 2015 within the wetlands, together with quantitative information on the changes of wetland area at the same locations. We found that, on average, the accumulation of sediment dominates, but a wide range of situations occur from sediment removal resulting in changes of elevation of up to a meter, to sediment accumulation up to more than half a meter. Reeds were in decline everywhere where sediment loss was identified, and also in locations with sediment accumulation below $50 \mathrm{~cm}$. Reed regeneration was only observed where sediment accumulation was higher than $50 \mathrm{~cm}$ in the studied period. From the perspective of water level regulation, this means that most wetlands cannot sustain the ongoing rise in water level, and that short periods of lower water levels are not sufficient for regeneration of most wetlands. Dedicated studies will be necessary in order to clarify the connection between lake bed topography, water levels, and wetland change, but it is already proven that the lake topography cannot be assumed as constant from the perspective of the wetlands, even at the time scale of a few decades.
\end{abstract}

Keywords: wetlands, reed die-back, water level, sediment dynamics, Lake Balaton

\section{Bevezetés}

\section{Elózmények}

Napjainkban az édesvízi növényzet és a hozzájuk tartozó élővilág megőrzése, óvása létfontosságúvá vált. A vizek üdülési célú használatával és a klímaváltozással különösen is felértékelődik a vízparti növényzettel borított élőhelyek és ezeken belül a nádasok szerepe. A nádas kulcsszerepet játszhat az édesvizek biokémiai folyamatiban, például a vizek foszforeltávolításában is, amely elősegíti a vízminőség javulását, ezen felül a nádasok elősegítik a talajvízkészletek feltöltődését, óvják a partot az eróziótól, és visszatartják az árvizeket. Ezek ismeretében is folyamatosan zajlanak nádpusztulást előidéző tevékenységek, ilyen például a vizek és a partok szennyezése, a partok beépítése, a lecsapolás, az idegenhonos fajok behozatala és ide tartozik a Balaton vízállásának magasan tartása, amely a turizmus és a hajózás feltételezett érdeke. Mára már több nemzetközi egyezmény is szabályozza a vizes élőhelyek védelmét, mint például a Ramsar-i egyezmény vagy a Natura 2000, amelynek elsődleges célja az emberi jelenlét fenntartása mellett a jó élőhelyállapot elérése.

Haslam vizsgálatai alapján a közönséges nádas kedvező élőhelye az alacsony fekvésű sekély tó (HASLAM, S. 1972), amire a Balaton tökéletes példa. A nádas jelenleg általában az 1,5 méteres vízmélységig terjed a tó hullámzástól védett, szerves anyagban viszonylag gazdag üledékú területein. A balatoni nádasok területe kb. $12 \mathrm{~km}^{2}$ és a többség (73\%) az északi partra koncentrálódott (Tóтн R. V. 2016). 
A tóparti nádasok pusztulása egy Európa-szerte ismert probléma, amely hazánkban a Balatont is érinti (1.ábra). E jelenség során az egységes, zárt nádas csomókra bomlik, amelyek között terjeszkedó, nyílt vizes lagúnák, csatornák alakulnak ki, majd a csomókat kidönti a hullámzás, és így a nádas korábbi területének 20-60\%-át is elveszítheti (VAN DER PUTTEN, W. H. 1997; KovÁCs M. 1994). A közönséges nád (Phragmites australis Cav. Trin ex Steud) alkalmazkodóképességét gyengíti a szerves anyagban gazdag üledék felhalmozódása. A rizómaszövedék közeibe és tetejére rakodó iszap a nádasban termelődő szerves anyaggal dúsulva ugyanis kitűnő táptalajt képez baktériumok és más mikroszkopikus élőlények számára, viszont a bomlás miatt oxigénhiányos körülmények alakulnak ki az üledékben, amelyek károsan hatnak a nád rizóma növekedésére. Az avar felhalmozódása pedig visszavezethető az állandó magas vízállásra (VAN DER PUTTEN, W. H. 1997), mert a Balatonon csak az alacsony vizú időszakokban tudja a felhalmozódott szerves anyagot kiöblíteni a vízlengés. Több kutatás is kimondja (pl. TótH R. V. 2016), hogy az alacsonyabb vízállás kedvező hatással van a nádas területek növekedésére. Ilyenkor a viharos szelek által előidézett keresztirányú vízállásváltozásoknak, illetve a hosszirányú vízlengéseknek nagyobb a nádast öblítő, iszapfelhalmozódást csökkentő hatása, mint magas vízállásnál (VIRÁG Á. 1998). A nádpusztulás jelentőségét mutatja, hogy nemzetközi együttműködésben vizsgálták és vizsgálják ma

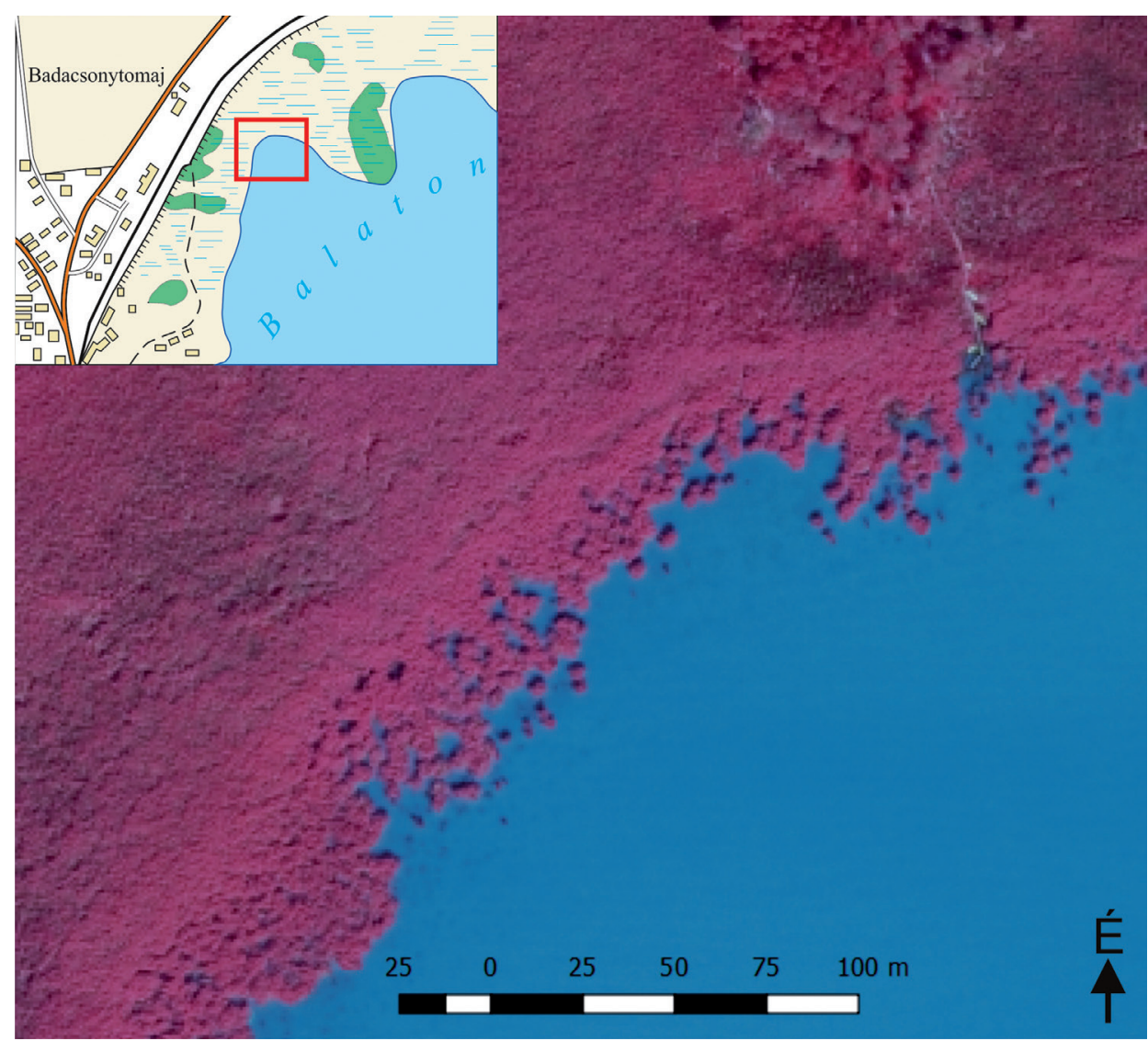

1. ábra A pusztuló nádas Badacsonytomaj közelében a 2003 évi országos légifelvételezés infravörös fotóján Figure 1 The reed stand in decline near Badacsonytomaj on the infrared photo of the 2003 national aerial photography 
is, feltárva annak feltételezett összefüggéseit a nádaratással (KÁRPÁTI I. et al. 1987), a vízminőséggel (HANGANU, J. et al. 1999), a genetikai változatossággal (ENGLONER, A. et al. 2010). A Balatonon Tóтн R. V. (2016) részletesen is összehasonlította az élettani és környezeti viszonyokat két egymással szomszédos nádasban, amelyek közül az egyik terjeszkedik, a másik pusztul, és megállapította, hogy a pusztulás és regeneráció kulcsfaktora az üledék oxigén ellátottsága. ZLINSZKY ANDRÁs és GERTHEIS ANNA légi felvételek alapján 73 mintavételi területen, közel hatvan év távlatában (1951, 1963, 1975, 1987, 2000, 2003 , 2010) vizsgálta a nádasok területváltozásait (ZLINSZKY A. 2013; GERTHEIS A. 2016). A vizsgálat során azokra a nádasokra koncentráltak, amelyek nem állnak közvetlen emberi hatás alatt (feltöltés, stégek, horgászkikötők). Ennek megfelelően a nagyobb nádasok belsejében definiáltak egységesen 200 méteres partszakaszokat (ezeket nevezzük mintavételi területeknek cikkünk további részében), ahol georeferált légifelvételek alapján 1:100 léptékben digitalizálták a nádas és a víz határvonalát. Az eredmények szerint az északi parti, mélyebb vízben, szerves üledéken élő nádasok jelentôs része pusztulásnak indult az 1970-es években, míg a déli parti, homokos üledéken álló nádasok folyamatosan terjeszkedtek. Az északi parti nádasok területváltozásai összefüggést mutattak a vízállással: alacsonyabb vízállású időszakban megindult a regeneráció, míg hosszabb, stabilan magas vizú időszakokban csökkent a nádas területe. A kapott eredmények alapján megállapítható, hogy a balatoni nádpusztulás kulcsfontosságú tényezője az alacsony vízállású időszakok hiánya, amely az üledék oxigénhiányát okozza (ZlinszKy A. 2013; GerTheis A. 2016; TóTH R. V. 2016).

A Sió-zsilip és csatorna 1863-ban történt megnyitása óta a Balaton vízszintje mesterségesen szabályozva van (BENDEFY L.-V.NAGY I. 1969). A zsilipkezelési szabályzatokban egyre magasabb minimumvízszintet írtak elő, kevés ingadozási szinttel, ugyanis a feltételezések szerint a hajózás és a turizmus érdekeit a magas és stabil vízállás szolgálja a legjobban (VIRÁG Á. 1998).

A tó vízszintszabályozása során a vizsgált időszakban többször is emelték az átlagos vízszintet, és napjainkban minden eddiginél magasabb szabályozási szintek vannak érvényben (2.ábra). Ez egyúttal a vízszintingadozás csökkentésével is jár, amely feltételezéseink

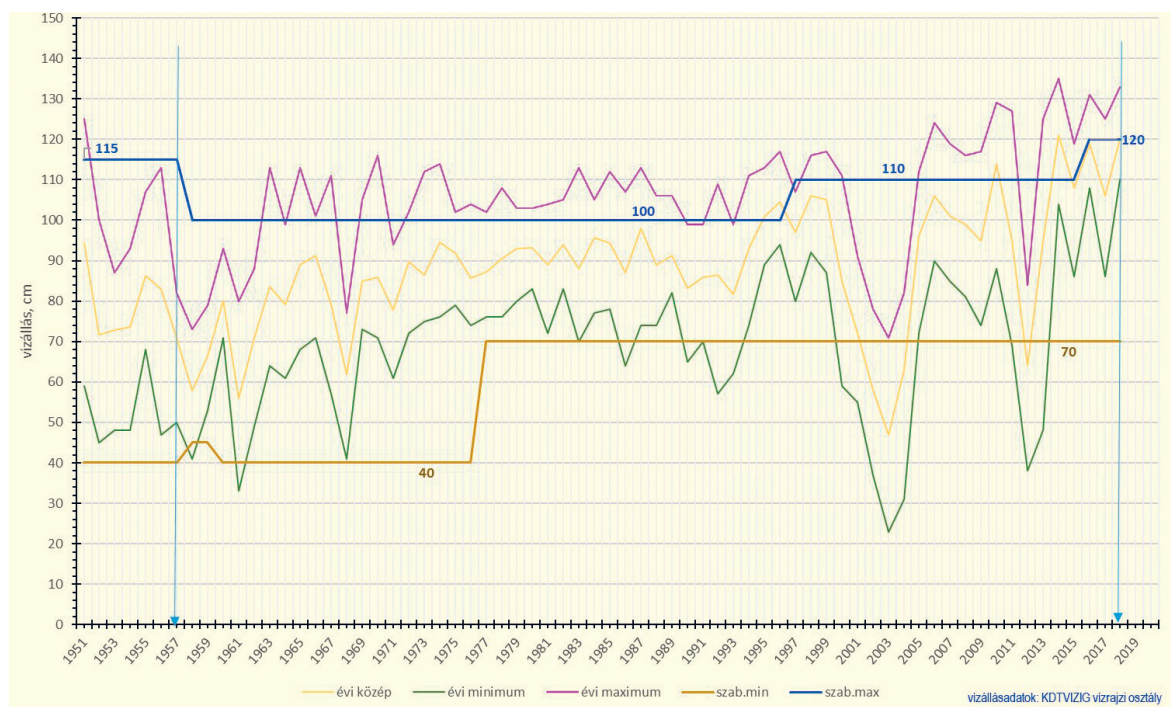

2. ábra A Balaton évi minimum, átlag és maximum vízállásai, és szabályozási minimum és maximum szintjei 1951 és 2018 között. Forrás: AlberT K. 2018.

Figure 2 Minimum, average and maximum water levels and minimum and maximum regulation levels of Lake Balaton between 1951 and 2018. Source: ALBERT K. 2018. 
szerint a nádasok károsodásához vezet. Vizsgálatunkkal adatokat szeretnénk szolgáltatni a Balaton vízszintjének átgondoltabb kezeléséhez a jövőben.

\section{Témafelvetés}

A vízmélységet egyrészt a tómeder térfogata, másrészt a benne tárolt víz mennyisége határozza meg. A meder alakja és változása a partközeli területen tehát befolyásolhatja a nádasok kiterjedését. Nagy egyszerűsítéssel ZLINSZKY A. (2013) eredményei alapján azt várnánk, hogy a mélyebb vízben álló nádasok pusztulóban vannak, míg a sekélyebb vizú nádasok terjeszkednek. Ez lehetővé tenné egy optimális vízszint megállapítását, amely mellett a nádasok többségének jó állapota biztosítható. Felmerül viszont a kérdés, hogy vajon állandónak tekinthető-e a meder a nádasokban, és ha nem, akkor annak milyen következményei vannak a tó vízszint-szabályozására.

Korábbi kutatások vizsgálták az összefüggést a vízszint és a nádasok állapota között. Célunk a meder dinamikájának bevonása ezekbe a vizsgálatokba, a mederváltozás mérésével és a nádasok változásaival való összehasonlításával. Kutatásunk eredményei a Balaton hosszú távú vízszintszabályozásának optimalizálását támaszthatják alá.

Kutatásunk célja tehát megvizsgálni, hogy van-e összefüggés a nádasok területváltozása és a meder változása között. Ha a nádasokkal borított területek nagysága a mederviszonyok változásától függetlenül alakul, akkor a medret állandónak tekintve vizsgálhatnánk, hogy melyik évben, milyen mély víz borította a nádasokat, vagyis hogyan hatott rájuk a vízmélység változása. Ha a terület- és mederváltozások között megfigyelhető az összefüggés, az arra enged következtetni, hogy a nádasoknak szerepe van az üledékfelhalmozódásban, vagy éppen fordítva, az üledékfelhalmozódás van hatással a nádassal borított területek nagyságára. Ebben az esetben a nádasok védelmére hozott intézkedéseknek tekintetbe kell venni az üledék felhalmozódását vagy elmosódását is.

Mennyiségi szempontból három kérdést kellett megvizsgálnunk:

- Hogyan változott általában véve a Balaton medermélysége a nádasok környékén 1975 és 2015 között?

- Hogyan változott a nádasok volt vagy jelenlegi területén a medermélység a vizsgált időszakban, és ez eltér-e az általános trendtől?

- Van-e összefüggés a nádasok változása (növekedése vagy pusztulása) és a meder felhalmozódása, illetve elmosódása között?

\section{Adatok és módszerek}

\section{Felhasznált adatok}

ZLINSZKY A. (2013) munkája során a nádassal borított területeket a Balaton partjánál 73 mintavételezési területen vizsgálta 7 különböző évben. A mintaterületek egyenként nagyjából 200 méteres partszakaszok voltak és a kutatás során a nádas területváltozásait hasonlította össze. Ezen vizsgálatok közül itt az 1975-ös és a 2010-es évi nádasterületeket használtuk fel, ugyanis ezekre az időszakokra álltak rendelkezésünkre megbízható mederadatok.

A 73 mintavételezési terület számát tovább csökkentettük a 2015-ös mederfelmérés alapján, mert nem mindegyik területen volt elegendő felmérési pont (3.ábra). Végezetül 23 mintavételezési terület maradt a leválogatás után, melyek nagyjából egyenletes eloszlással lefedik azt a területet, amit az eredeti 73 mintahely. 


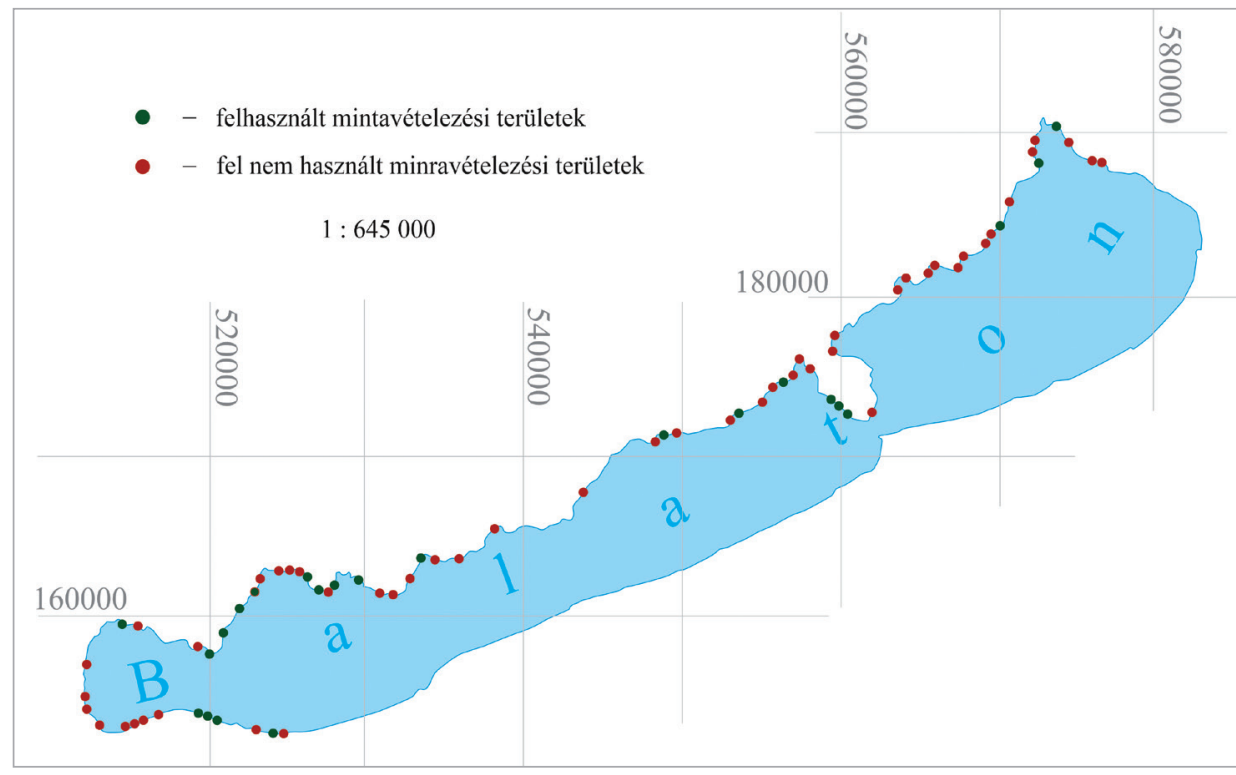

3. ábra A 23 felhasznált mintavételezési terület a 73-ból
Jelmagyarázat: zöld - felhasznált mintavételezési területek; piros - fel nem használt mintavételezési területek
Figure 3 The 23 used sampling areas out of 73
Legend: green - sampling areas used; red - unused sampling areas

Mivel rendelkezésre állt összesen hét, különböző évből származó légifelvétel-alapú nádas terület adatsor, de csak két különbözó évből származó Balaton mederadat, kénytelenek voltunk a vizsgálatban átfogott időszakot a medermodellek hozzáférhetőségéhez igazítani. Ez a két medermodell lefedettségét és részletességét tekintve is különböző, amit az eredmények kiértékelésénél tekintetbe kell vennünk.

\section{Az 1975-ös Balaton Vírajzi Atlasza}

A Balaton mindeddig legrészletesebb mederfelmérését a VITUKI végezte 1974-75 között (SASS J. 1979). A felvételhez az Atlas-Echolog mérőberendezést használták, ami ultrahang segítségével méri a vízmélységet és tetszőleges méretarányban folyamatosan rajzolja a mederprofilt. A mérés során a nádassal borított területeket munkagépek segítségével a szelvényirányokban letaposták, így a nádassal borított részeket is feltérképezték. A vízrajzi térképeken szereplő mélységvonalakat a 104,84 m Adria feletti szinthez viszonyítva szerkesztették meg (4.ábra). Az 1:25000 méretarányú vízrajzi térképeken a 0,5 méteres szintkülönbségú mélység vonalak +75 cm-es vízállásra vonatkoznak (SASS J. 1979). Ezeket a térképeket egy korábbi kutatás során szkennelték, a rajtuk lévő koordinátahálózat alapján georeferálták, majd a digitalizált szintvonalakból natural neighbour interpolációval digitális medermodellt állítottak elő (ZLINSZKY A. et al. 2010) amelyet ehhez a kutatáshoz is felhasználtunk.

\section{A 2015-ös mederfelmérés}

A BVK (Balaton Vízügyi Kirendeltség) 2015-ben feladatául túzte ki a Balaton feltérképezését. A mérés elsősorban a hajózás érdekében készült, hogy biztonságosabbá és tervezhetőbbé tegye azt, ugyanis az 1975-ös felmérés óta a tó oly mértékú változásokon 


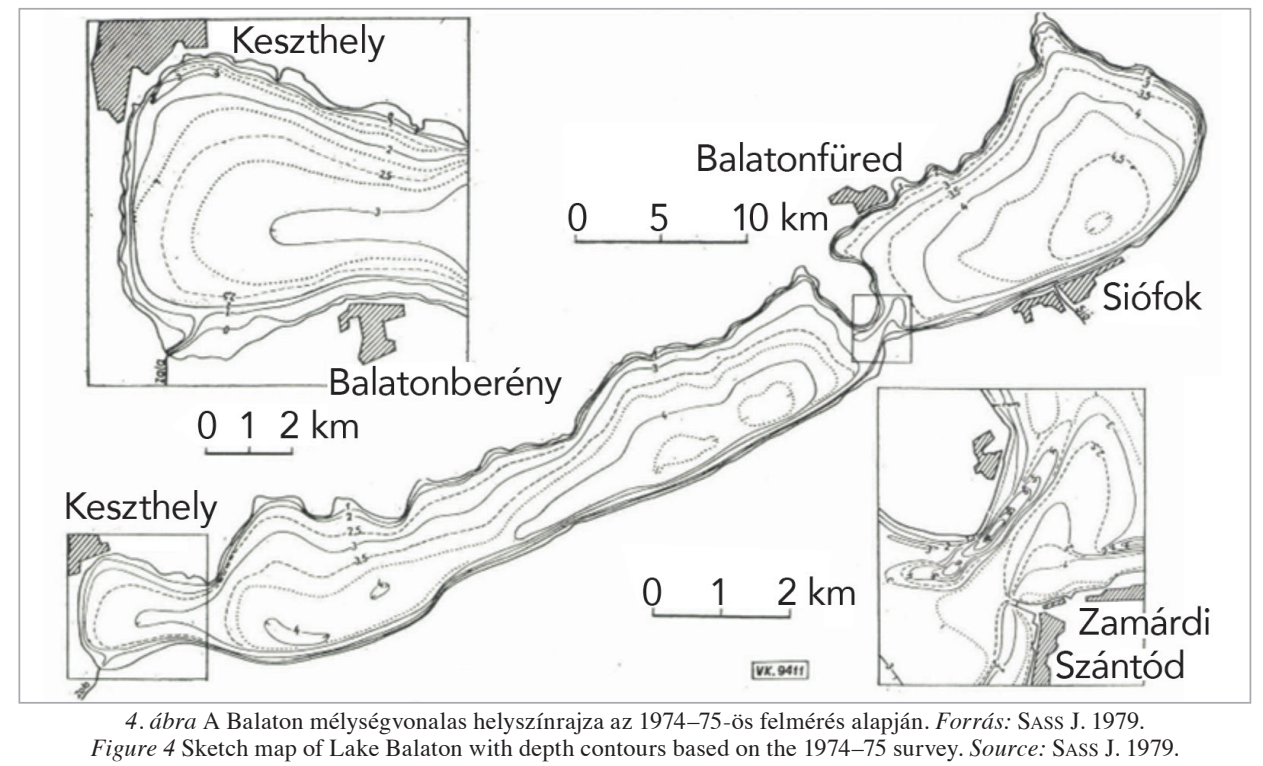

ment keresztül, hogy az adatok frissítése elengedhetetlenné vált. A felmérést a tervek szerint az 1975-ös szelvényeket pontosan ismételve hajtották volna végre, a nyílt vízen a „Csoma János” mérőhajóval, DESO 14 ultrahangos vízmélységméró és Leica 1200 RTK GPS segítségével (AlBERT K. 2018). A sekélyvízi méréseket a Közép-dunántúli Vízügyi Igazgatóság munkatársai végezték egy kenukból összeállított katamaránon, amely kellô stabilitást biztosított a GPS és a mélységmérő szonár megfelelő múködéséhez (PÉCSELI P. 2016). Sajnos az idojárás és a mérés időbeli korlátai nem tették lehetővé a sekély vízben, illetve a nádasban az összes 1975-ös szelvény felmérését. A sekélyvízi felmérések során a nádassal borított területekre nem hatoltak be,inkább csak érintették azokat, de sok esetben a felmért pontok távol helyezkedtek el az egyes mintavételezési területtől. Megállapítható, hogy az 1975-ös felméréshez képest részletgazdagsága csekélyebb a nádasok területén belül, de ahol a mintavételezési területre van adat, ott a pontsűrúség miatt felhasználható volt.

Az adatsorok a felmért pontokat tartalmazták, illetve készült ezekból egy szintvonalas domborzatmodell is a Balaton medrének partközeli részére. Az adatsorok közül a 'nyers' felmért pontokat használtuk fel alapadatként, ugyanis az interpolációs eljárással feldolgozott másodlagos adatok, mint például egy szintvonalas modell, a módszertől függóen hibákkal terheltek (ALBERT G. 2018). Továbbá megvizsgálva a pontok elhelyezkedését a szintvonalakhoz képest, észrevehető, hogy jelentős extrapolálás történt felméretlen területekre (5. ábra). Ez azt jelentette, hogy a jelen vizsgálat csak azokra a nádas mintavételi szakaszokra korlátozódhatott, ahol a 2015-ös felmérés során konkrét terepi mederfelmérések történtek a nádason belül, vagy legalább azok közvetlen előterében. Összesen 23 ilyen mintavételi területet találtunk (ZLINSZKY A. 2013) 73 mintahelye közül.

\section{Módszerek}

Adott volt tehát két légifelvétel-alapú nádas körvonal adatsor (1975 és 2010), valamint egy digitális medermodell raszter (1975), továbbá egy mederfelmérésnek az adatsora vektorosan, pontokban (2015). A mederváltozások eloszlásának kiszámításához a 2015- 


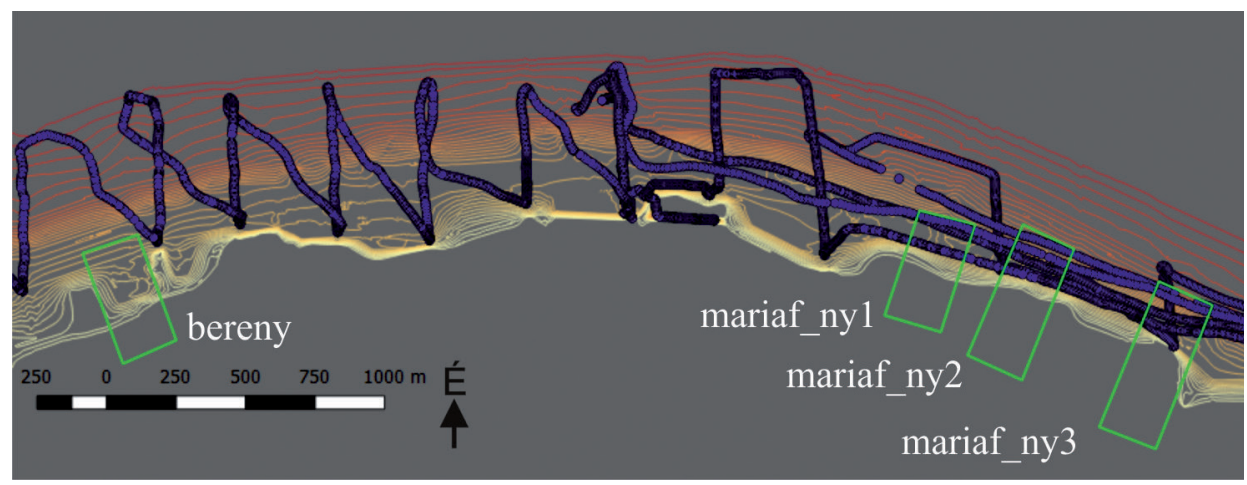

5. ábra A 2015-ös felmérés pontjai és az azokból elóállított szintvonalak Figure 5 Points of the 2015 survey and contours drawn from them

ben mért medermagasságokból közvetlenül kivontuk az 1975-ös raszteres medermodell magasságait a megfelelő helyen. Eredményként egy táblázatot kaptunk, amely pontonként tárolja a meder 1975-ös modellezett és 2015-ös mért tengerszint feletti magasságát.

Ahhoz, hogy a nádason belül a mederváltozások eloszlását kiszámítsuk, már nem volt elég a pontszerú összehasonlítás, így a 2015-ös mérési pontok adataiból is raszteres medermodelleket állítottunk elő, minden egyes nádas mintavételezési szakasz területére külön. Megőriztük a korábban használt paramétereket, azaz a 10 méteres felbontást és az interpolációs eljárást (natural neighbor). Az így létrejött 23 db 2015-ös lokális medermodellnek szintén képeztük a különbségét az 1975-ös medermodell értékeivel, pixelenként. Az eredményként létrejött adatbázisban az egyes pontok attribútumtáblázata tartalmazza a pont tengerszint feletti magasságát balti magassági rendszerben; csak az 1975-ös mederadatoknál kellett átszámítást végezni adriai magassági rendszerből. Az interpolálást Surfer szoftverben végeztük.

Következő lépésként az 1975-ös és a 2010-es nádassal borított területek poligonjainak vettük a szimmetrikus különbségét. Az így kapott poligon csak azt a területet fedte le, ahol egyik évben volt, a másik évben pedig nem volt nádas az adott helyen, tehát azokat a területeket, ahol 1975 és 2015 között a nádas kipusztult, vagy ahova új nádas nőtt ebben az időszakban. Az elóbb létrehozott mederváltozás értékét mutató rasztereket ezekre a poligonokra leválogattuk. Mivel a poligonok alakja szabálytalan, ezért sokszor a rácspontok nem esnek a poligon területére, így ott adathiány keletkezik. Az adatsűrúség érdekében a 10 méteres felbontást bilineáris módszerrel 5 méteres felbontásra növeltük. Így létrejött egy részletes adatsor, amely arról nyújt információt, hogy milyen mederváltozások zajlottak le azokon a területeken, ahol változott a nádassal borított területek nagysága is.

A két medermodell, illetve a velük kvázi egykorú nádas állapot idején az átlagos vízszint különbözött, így ezt a különbséget is figyelembe kellett vennünk annak a kiszámításához, hogy milyen mély vízben álltak a növekvő, illetve csökkenő területû nádasok. Ezért a kapott különbség-rasztert tovább korrigáltuk a két vizsgált időszak átlagos vízállásának a különbségével, ami 8,2 cm-et tett ki (6. ábra). Így már ki tudtuk számítani az egyes nádas mintavételi területek vízmélységének az eloszlását is.

A táblázatban szereplő adatoknak, azaz a mederváltozásnak és a vízmélységnek kiszámoltuk az értékeik átlagát és azok szórását, továbbá elkészítettük az adatok hisztogramját is (7. ábra). Továbbá a táblázatokban feltüntettük az 1975. és 2010. évi mintavételezési területre eső nádasok területét $\mathrm{m}^{2}$-ben megadva, illetve ezek különbségét, ahol a pozitív érték a nádas által borított terület növekedését, negatív érték pedig azok csökkenését jelenti. 

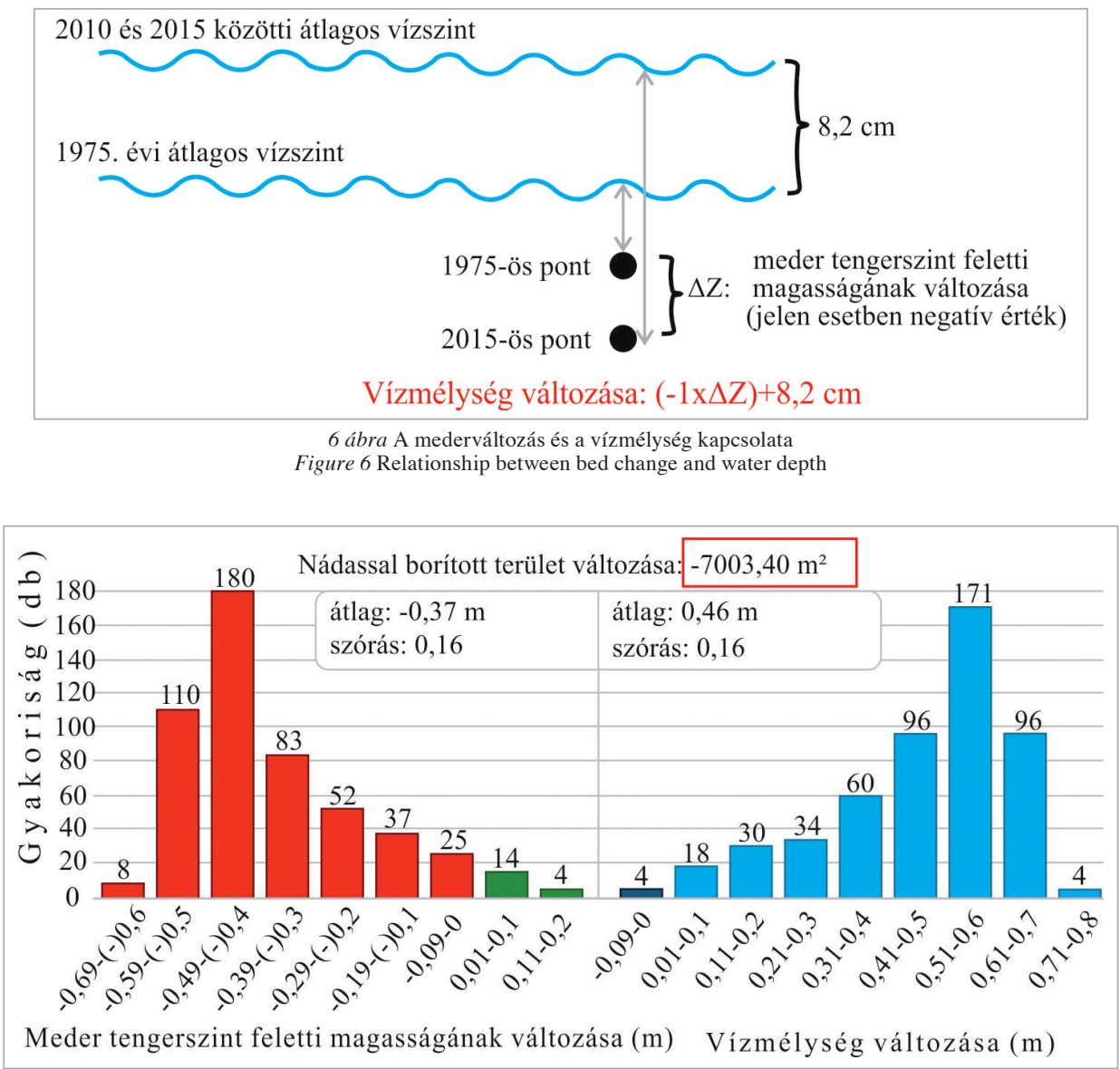

7. ábra A Szigliget egyik mintavételezési területéhez elkészített táblázat, ami bemutatja a megváltozott nádas területen meder- és vízmélység változásának átlagát, szórását és az adatok hisztogramjait, illetve a nádasok területváltozását Figure 7 Table for one of the sampling areas of Szigliget, which shows the mean, standard deviation, and data histograms of the reedbed and water depth changes in the reedbed area and the reed area change

\section{Eredmények}

A Balaton egészét tekintve, a 2015-ös mederfelmérés minden pontját összehasonlítva az ugyanott 1975-ben térképezett vízmélységgel (8.ábra) kimutatható, hogy a különbségek átlaga csekély, 3,6 cm-es feltöltődést mutat 29,2 cm szórás mellett. Lokális szinten azonban változatosabb a kép! Azokon a területeken, ahol üledékfelhalmozódás történt, gyakori volt a 0-20 cm-es és a 20-40 cm-es felhalmozódás. Szintén gyakori a kismérvú mélyülés $(0-20 \mathrm{~cm})$, de ritkábban előfordultak extrém, akár egy méternél is nagyobb mértékú üledék elmosódások is. A nádasok előterében tehát a meder korántsem tekinthető állandónak: a leggyakoribb jelenség a $40 \mathrm{~cm}$ körüli elmosódás volt, továbbá sehol nem történt $20 \mathrm{~cm}$-t meghaladó feltöltődés.

Az egyes nádasok területén belül vizsgálva a változásokat, az általános trendtől eltérő folyamatokat tapasztalunk: a nádasok döntő többségében üledék felhalmozódás zajlott. 23 nádasból 17 helyen találunk pozitív változást a meder átlagos tengerszint feletti magasságában, és 


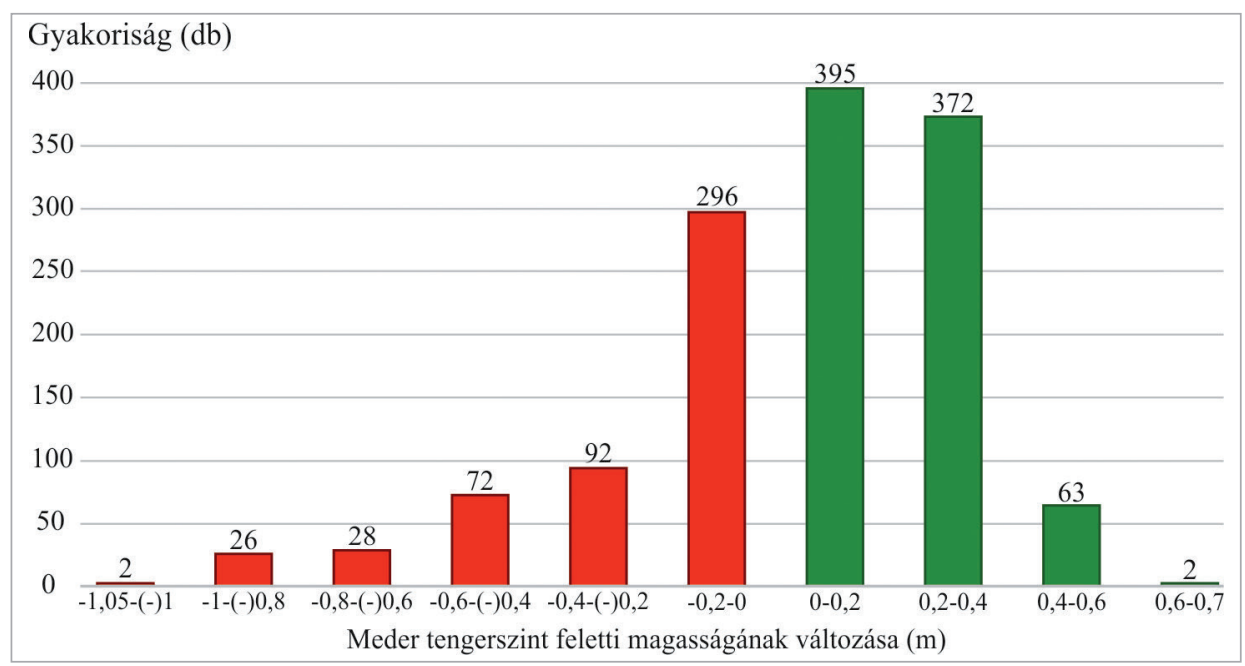

8. ábra Balaton medrének tengerszint feletti magasságváltozásának megoszlása 2015 és 1975 között a mintaterületekre eső 1348 pont alapján (A pozitív értékek a mederfenék emelkedését, a negatív értékek süllyedést jelölnek)

Figure 8 Distribution of the altitude change of the Balaton lake bed between 2015 and 1975 based on 1348 sample plots (Positive values indicate the rise of the lake bottom, negative values represent the descent)

csak 6 helyen elmosódást. Ez utóbbiak közül két további helyen 10 cm alatti a változás. A felhalmozódás mértéke akár $70 \mathrm{~cm}$ fölött is alakulhatott, míg az elmosódás maximuma $52 \mathrm{~cm}$ volt.

Végül összevetve a mederváltozást a nádasok területváltozással, egyértelmúen kizárható a két folyamat függetlensége (9. ábra). A vizsgált területek két csoportra oszthatók: az egyikben növekedett a nádasokkal borított területek nagysága, míg a másikban csökkent. Ezek választója körülbelül 52 centiméternél van, ami kb. 44 centiméteres vízmélység csökkenést jelent. Ahol a meder feltöltődése 52 centiméternél több volt, ott a nádasok területe növekedett, ahol kevesebb volt a feltöltődés vagy esetleg mélyült a meder, ott pedig csökkent a nádasok területe.

Alátámasztást nyert, hogy a Balaton medre nem tekinthető állandónak a nádasok szempontjából, és dinamikusan változik néhány évtizedes léptékben is, ez a változás pedig szorosan összefügg a nádasok területváltozásaival

\section{Diszkusszió és konklúzió}

Felmerülhet a kérdés, hogy a más korból, más felmérési eljárással mért adatok összevetése mennyire ad valós képet. Sajnos különösen az idősor-alapú vizsgálatok során kénytelenek vagyunk az elérhető legjobb, de nem tökéletes adatokat felhasználni, és a következtetések levonásában az adatok pontatlanságára figyelemmel lenni. A medermodellek elkészítése során az adatsorokban kiugró értékeket nem tapasztaltunk. Hibaforrás lehet, hogy míg a 2015-ös modell 'nyers' felmért pontokból készült, addig az 1975-ös modell izobátok digitalizálásából nyert adatokból, amelyek már előtte valamilyen eljárás során fel lettek dolgozva. Az 1975-ös adatokból természetes szomszédok interpolációval előállított modell vertikális pontosságát 10-15 cm-re becsüljük, amely a mélységmérésre használt berendezés hibájából (5 cm, SASS J. 1979) és az interpolációból adódik. Ezt alátámasztja SzEMES et al. (2015) medermodellezési tanulmánya is, akik hasonló módszerrel $15 \mathrm{~cm}$ átlagos modellezési hibát becsültek ugyanebből az alapanyagból. Ahol a 2015-ös adato- 


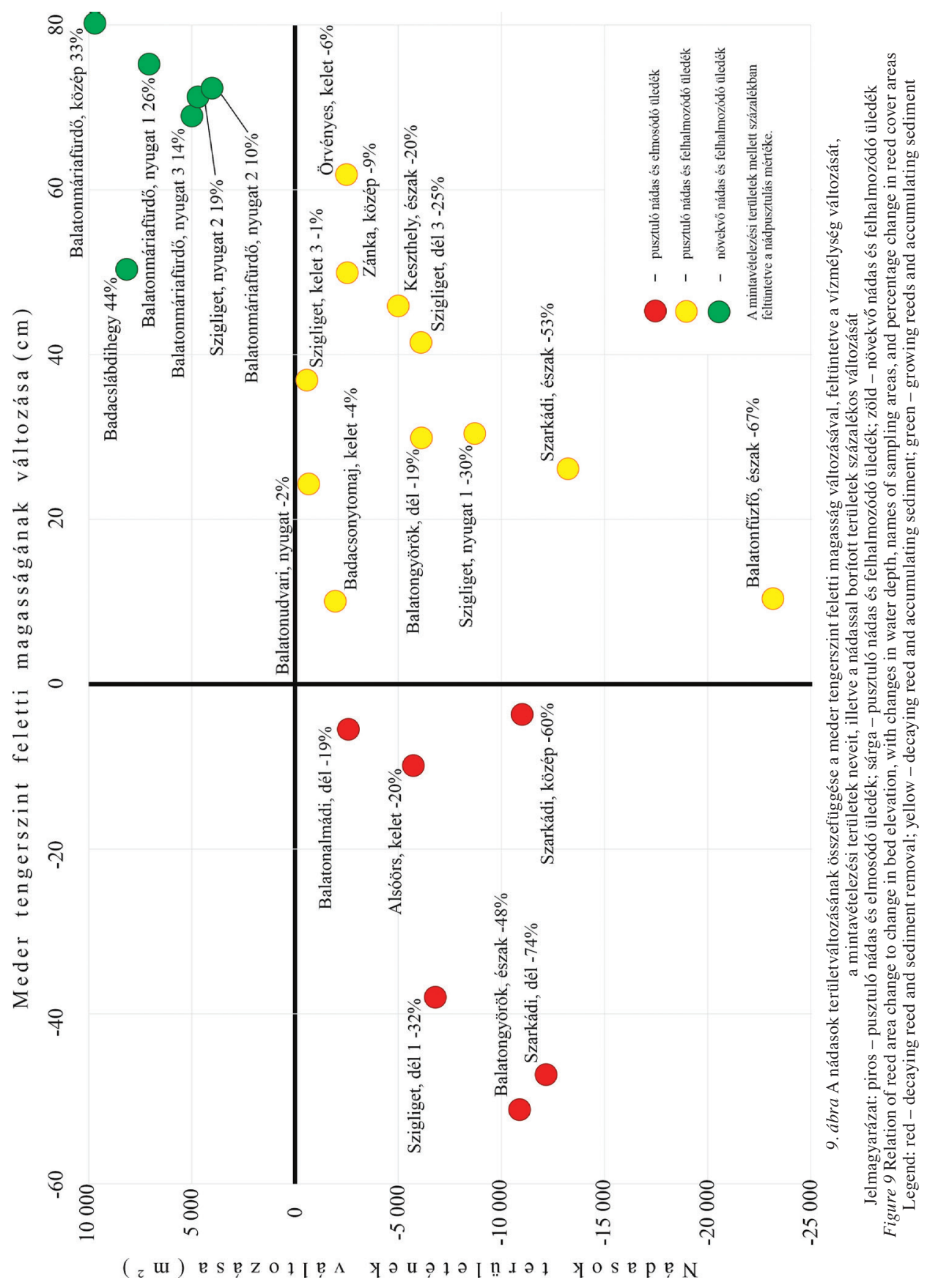


kat interpoláció nélkül használjuk, ott azok hibája a műszer érzékenységéből származik, ami néhány centiméter körülire tehető. A digitalizálásból fakadó hibalehetőség nem csak a domborzatmodelleknél áll fent, hanem a nádassal borított területek állományainál is. Itt a hibák a georeferálás pontosságából és a digitalizálás hibájából állnak össze. Mindkét adatsor pixelmérete $30 \mathrm{~cm}$ alatti, és a digitalizálás olyan nagyításon történt, ahol az egyes pixelek láthatóak voltak. A georeferálás hibája az 1975-ös adatokra maximálisan 5 méter, a 2015-ös adatokra maximum $30 \mathrm{~cm}$ képen belül. 200 méteres partszakaszon 5 méter hiba mintegy $1000 \mathrm{~m}^{2}$ területmérési hibát okoz elméletileg, a kapott területváltozások ezt a 23 mintából 21 esetben meghaladták. Mind a medermodellek, mind a területváltozás tekintetében feltételezzük továbbá, hogy a felhasznált pontok nagy száma és a várhatóan véletlenszerúen megoszló hibák miatt ezek kevéssé befolyásolják a következtetéseinket.

A vizsgálatok eredménye alapján az általunk vizsgált, nádassal borított területeket három különböző csoportba tudjuk besorolni (10. ábra): ahol pusztul a nádas és elmosódik az üledék, ahol pusztul a nádas és felhalmozódik az üledék, illetve ahol növekszik a nádas és felhalmozódik az üledék. Továbbá az eredmények alapján az is megállapítható, hogy a nádasok által borított területek változása és a meder tengerszint feletti magasságváltozása összefügg, mivel a növekvő nádasterületek kivétel nélkül csak felhalmozódó üledéken vannak, és az intenzív elhordás alatt álló területeken kivétel nélkül intenzíven pusztul a nádas. A legfontosabb felmerülő kérdés, hogy vajon az elpusztuló nádasok helyén válik lehetségessé az üledék elhordása, vagy épp ellenkezőleg, az elmosódó üledékú területeken pusztul el a nádas? Erre egyértelmú választ csak nagy léptékú terepi kísérletek adhatnának, de azt már a jelen vizsgálat is láthatóvá teszi, hogy felhalmozódó üledéken is történhet nádpusztulás, viszont elmosódó üledéken sehol nem történik regeneráció. Az élettani vizsgálatok szerint az üledék oxigénhiánya a nádas állományának szétszakadozását, csomósodását

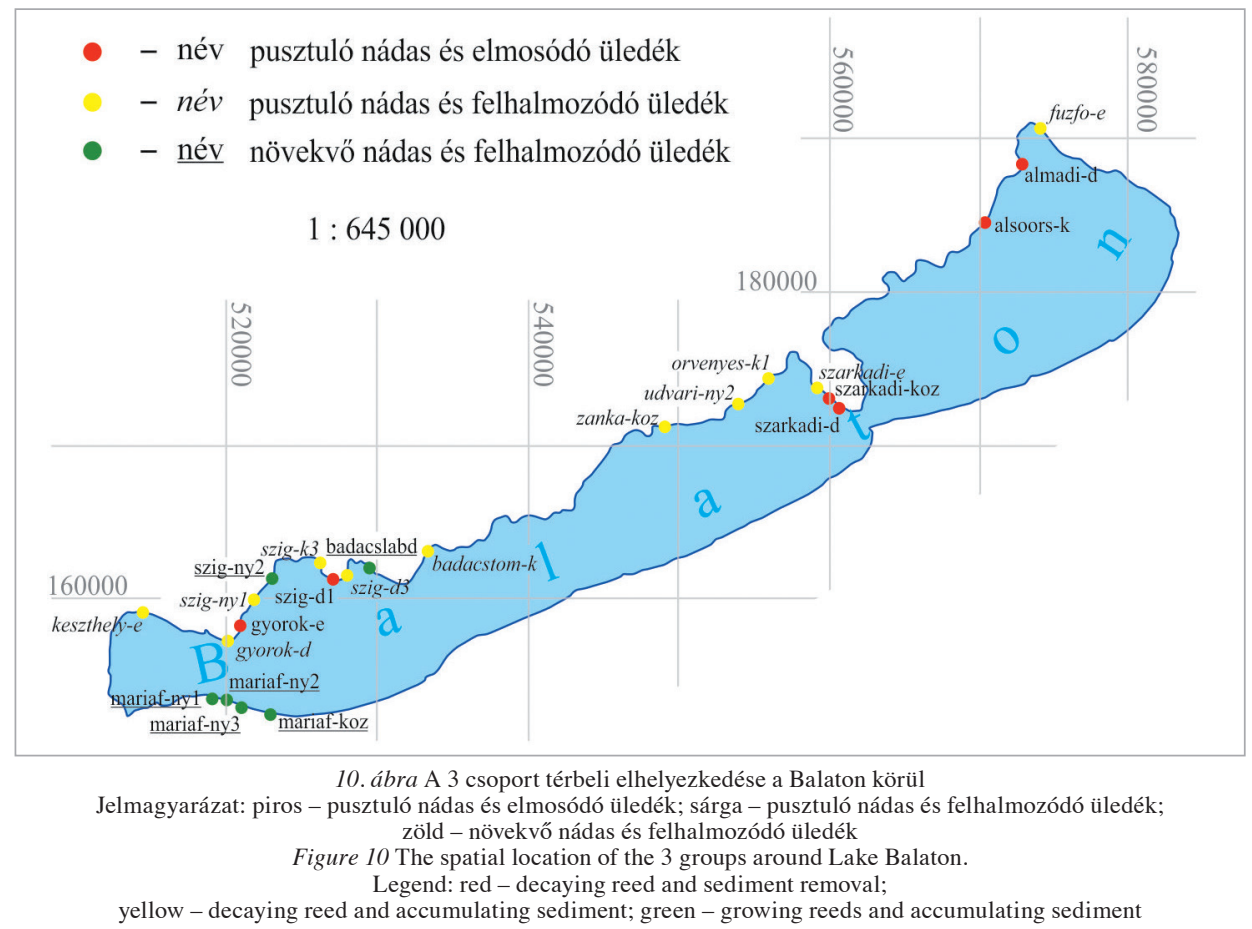


okozza, amely viszont lehetôvé teszi, hogy a hullámzás elmossa a nádast és vele együtt az üledéket. Így tehát feltételezhetően a nádpusztulás következménye az üledék elmosódás.

Mindenesetre úgy találjuk, hogy a pusztulóban lévő nádasok jelentős részén üledék elmosódás is zajlik. Ezek a nádasok tehát csak akkor nyerhetik vissza korábbi területeket, ha nem csak rövid időre alakul ki regenerációt lehetôvé tevő alacsony vízállás, hanem rendszeresen visszatérnek a nádas számára kedvező időszakok, és a terjeszkedés során ezeken a helyeken is üledék felhalmozódás alakulhat ki. A több lépcsőben zajló vízszint emelést csak azok a nádasok vészelték át sértetlenül, amelyek területén kimondottan intenzív, legalább fél méteres mederváltozást okoz az üledék felhalmozódása. Az általunk vizsgált nádas mintahelyeknek csak az egynegyede tartozik ebbe a típusba, a Szigligetiöböl északi és déli partján.

Mivel egy mintavételezési terület nagyjából egy 200 méteres partszakaszt fed le, a vizsgálat megközelítóleg összesen 4600 méternyi partszakaszra vonatkoztatható, ami a Balaton teljes partvonalának mintegy ötvened része. Annak érdekében, hogy az egész tó területére következtetéseket vonhassuk le, elengedhetetlen és egyben sürgősnek is tekinthető egy részletes mederfelmérés, ami a nádasokkal borított területekre is kihat. Ezen adatok birtokában lehet majd a jelenleginél részletesebben vizsgálni a nádasok és a mederváltozás közötti összefüggéseket. Ugyanakkor kísérleti úton is vizsgálható, hogy az üledékelmosódás csökkentésével vissza lehet-e fordítani a nádpusztulást a legrosszabb állapotú helyeken, üledékcsapdás vizsgálatokkal pedig számszerúsíthető az üledék felhalmozódása és elmosódása rövidebb távon is.

A jelenlegi eredményeink alapján megállapítható, hogy a ZLINSZKY A. (2013) eredményei által sugallt szemlélettel ellentétben nem lineáris összefüggés van a nádasok állapota és a vízmélység között. Sajnos nem állapítható meg „optimális” állandó vízmélység, amelyen a mély vízben álló nádasok állapota ugyan romlik, de a sekély vízben állóké javul. Továbbra is igaz, hogy a mélyebb vízben álló északi parti nádasok között több volt a pusztuló, mint a sekélyebb vízben álló déli parti nádasok között. Csak azokon a területeken tud a nádas növekedése lépést tartani a mesterségesen egyre magasabban tartott vízszinttel, ahol az üledék felhalmozódása kimondottan intenzív - mindenhol máshol csökkent a nádasok területe. Nem indulhatunk ki azonban abból, hogy egy rövid sekély vizú időszakban a pusztuló nádas visszanyerheti teljes korábbi területét, hiszen lehetséges, hogy az üledék elmosódásával megnövekedett a lokális vízmélység és a nádas már csak korábbi területének egy részét tudja visszafoglalni. Abból sem indulhatunk ki, hogy mindenütt biztosítva van a nádas jövője a megemelt vízszint mellett is, ahol üledékfelhalmozódás zajlik. Az általunk vizsgált területeken zajló, részben drasztikus változások felhívják a figyelmet a nádasok számára kedvezőbb új vízszint-szabályzás sürgősségére. Míg korábban azt feltételeztük, hogy rendszeresen visszatérő néhány hónapos alacsony vízszintú időszakokkal helyreállíthatóak a nádasok, a jelen vizsgálat eredményei inkább azt sugallják, hogy az átlagos vízállás tartós csökkentése is szükséges. A hosszú távú átlagos vízszint emelése csak olyan ütemben lehetséges a nádasok károsodása nélkül, hogy az üledék felhalmozódása lépést tartson a vízszint növekedésével.

A vizsgálat során különböző korú adatsorokat vetettünk össze, és vizsgáltuk, hogy milyen összefüggések vannak a mederváltozás, és a nádassal borított területek megváltozása között. Megállapítottuk egyrészt, hogy növekvő nádast kizárólag felhalmozódó üledékű területeken találunk, másrészt, hogy a pusztuló nádasok megoszlanak aszerint, hogy üledékük felhalmozódik, vagy elmosódik. A terjeszkedő nádasokon további területnövekedést várunk évtizedes távlatban, a területcsök kenést szenvedő nádasok pusztulása várhatóan megáll ott, ahol az üledék nem mosódik el. Ahol azonban a nádasok területe csökken és az üledék elhordása folyamatos, ott a nádas akár teljesen is eltúnhet. 


\title{
Köszönetnyilvánítás
}

A kutatást a PD 115833. számú OTKA/NKFIH pályázat támogatta.

\author{
AlBert GÁSPÁr \\ ELTE IK Térképtudományi és Geoinformatikai Tanszék, Budapest \\ albert@ludens.elte.hu
}

ZLINSZKY ANDRÁS

Ökológiai Kutatóközpont, Tihany

zlinszky.andras@okologia.mta.hu

GYENESE TAMÁS

HungaroControl Magyar Légiforgalmi Szolgálat Zártkörúen Múködő Részvénytársaság, Budapest

gyenesetomi@gmail.com

\section{IRODALOM}

Albert G. 2018: 3D geológiai modellek fejlesztése térinformatikai szemlélettel. - Beau Bassin: GlobeEdit. 2018. $168 \mathrm{p}$.

Albert K. 2018: A 2015. évi Balaton mérés. - KDVVIZIG Székesfehérvár, Budapest (belső jelentés).

Bendefy L.-V. Nagy I. 1969: A Balaton évszázados partvonalváltozásai. - Műszaki könyvkiadó, Budapest.

GERTHEIS A. 2016: Nádasok hosszú távú dinamikájának térképezése. - Diplomamunka, ELTE IK Térképtudományi és Geoinformatikai Tanszék, Budapest.

Engloner, A.-MAJor Á.-PodAni, J. 2010: Clonal diversity along a water depth gradient in a declining reed stand as detected by three different genetic methods. - Aquatic Botany 92. 1. pp. 1-8.

Hanganu, J.-Mihail, G.-CoOPs, H. 1999: Responses of ecotypes of Phragmites australis to increased seawater influence: a field study in the Danube Delta, Romania. - Aquatic Botany 64. 3-4. pp. 351-358.

Haslam, S. 1972: Biological Flora of the British Isles, Phragmites communis Trin. - Journal of Ecology 60. pp. 585-610.

KÁRPÁTI I.-KÁRPÁTI V.-WolCSÁNSZKY, S. E. 1987: Die Wirkung der maschinellen Ernte auf das Schilf. BfBBericht 62. pp. 55-62.

Kovács M.-Szabó S.-Busics I.-Kaszab L. 1994: A Balatoni nádasok területének változása, degradációjuk. - Magyar Hidrológiai Társaság Országos Vándorgyúlése XII. pp. 250-257.

PÉCsELi P. 2016: A Balaton feltérképezése. - Közép-dunántúli Vízügyi Igazgatóság, http://www.kdtvizig.hu/ hu/kdtvizig-aktualis/65eb0713-76d8-4222-99e9-d956324781f0/2, Letöltve: 2018. január 4.

VAN DER PUTTEN, W.H. 1997: Die-back of Phragmites australis in European wetlands: an overview of the European Research Programme on Reed Die-Back and Progression (1993-1994). - Aquatic Botany 59. pp. $263-275$.

SASS J. 1979: A Balaton vízrajzi felmérése. - Vízügyi közlemények 4. pp. 560-581.

Szemes É.-Telbisz T.-VARGA GY.-NovÁKy B. 2015: A Balaton vízkészlet-változásának vizsgálata digitális terepmodellek alkalmazásával. - Földrajzi Közlemények 139. 2. pp. 92-107.

Tо́тн R. V. 2016: Reed stands during different water level periods: physico-chemical properties of the sediment and growth of Phragmites australis of Lake Balaton Hydrobiologia 778. pp. 193-207.

VIRÁG Á. 1998: A Balaton múltja és jelene. - Egri Nyomda, Eger.

ZlinsZKy A.-MolnáR G.-HerodeK S. 2010: A Balaton medrének digitális geomorfológiai vizsgálata.-Hidrológiai Közlöny 88. pp. 239-241.

ZlinsZky A.-Tóth V.-Pomogy P.-TimÁR G. 2011: Initial report of the AIMWETLAB project: simultaneous airborne hyperspectral, lidar and photogrammetric survey of the full shoreline of Lake Balaton and KisBalaton, Hungary. Geographia Technica 13. 1.

ZLINSZKY A. 2013: Mapping and conservation of the reed wetlands on Lake Balaton. - Balaton Limnological Institute, Centre for Ecological Research of the Hungarian Academy of Sciences, Budapest. 127 p. 